\title{
STK36 Gene
}

National Cancer Institute

\section{Source}

National Cancer Institute. STK36 Gene. NCI Thesaurus. Code C150324.

This gene is involved in the regulation of GLI zinc-fing er transcription factor family activity. 